\title{
Peran Pola Asuh Orangtua di Era Digital
}

\author{
Aslan \\ Institut Agama Islam Sultan Muhammad Syafiuddin Sambas \\ aslanmarani88@yahoo.com
}

\begin{abstract}
Technological developments are increasingly rapid in the digital age today, causing the values that are born, both positive and negative also experience a tremendous surprise for humans. From these surprises, so the role of parents in educating their children also changes by the development of their times. In the 80, parents in educating their children must have experienced a difference in the digital age today. The parenting style that initially experienced differences from other parents, which only applied authoritarian, permissive, democratic types of parenting, had experienced success in educating children, but in the age of the digital era, the three parenting styles would not succeed, if they did not synchronize according to the time of the situation and conditions in terms of parenting.
\end{abstract}

Keywords: Synchronization; Parenting Role; Digital Era

\begin{abstract}
Abstrak
Perkembangan teknologi yang semakin pesat di era digital sekarang ini, menyebabkan nilainilai yang dilahirkan, baik positif maupun negatif ikut juga mengalami kejutan yang luar biasa juga bagi manusia. Dari kejutan tersebut, sehingga peran orangtua dalam mendidik anaknya ikut juga mengalami perubahan sesuai dengan perkembangan zamannya. Di era 80-an, orangtua dalam mendidik anaknya, pasti mengalami perbedaan di era digital saat ini. Pola asuh orangtua yang pada awalnya mengalami perbedaan dari orangtua lainnya, yang hanya menerapkan tipe pola asuh otoriter, permisif, demokrasi, sudah mengalami keberhasilan dalam mendidik anak, tetapi di zaman era digital, maka ketiga pola asuh tersebut tidak akan berhasil, jika tidak melakukan sinkronisasi sesuai waktu situasi dan kondisi dalam hal mengasuh anak.
\end{abstract}

Kata kunci: Sinkronisasi; Peran Pola Asuh Orangtua; Era digital

Manusia dalam kehidupannya tidak terlepas dari pendidikan, baik dalam lingkungan keluarga, sekolah maupun masyarakat. Dalam lingkungan keluarga, peran yang paling penting memberikan pendidikan adalah kedua orangtuanya, kemudian sanak saudaranya. Setelah anak memperoleh pendidikan dalam lingkungan keluarga, maka dilanjutkan lagi dengan pendidikan selanjutnya yakni pendidikan formal yang didapatkan dalam lingkungan sekolah. 
Peran pendidikan yang sebelumnya diberikan oleh orangtua telah tergantikan oleh guru di sekolah. Kemudian, setelah pendidikan dalam keluarga dan sekolah, maka anak-anak mendapatkan pendidikan pada lembaga di masyarakat.

Pendidikan terus berjalan seiring umur yang kita miliki, sehingga pendidikan disebut juga life long education, tetapi pendidikan ikut juga mengalami perubahan, seiring dengan zaman dan waktunya. Menurut (Toffler, 1980) dalam bukunya The Third Wave, bahwa perubahan yang dialami manusia saat ini mengalami tiga gelombang, yakni masa pertanian, industri dan masa sekarang. Dari masa pertama dan kedua telah dilewati oleh manusia dan saat ini manusia hidup di era informasi. Dalam hal ini juga, (Mujiburrahman, 2015, 2017a, 2017b), sebagai Guru Besar dalam bidang sosiologi Agama, menjelaskan bahwa perubahan dari "generasi mesin tik sudah diganti oleh generasi elektronik". Zaman ini perkembangan terakhir media elektronik adalah internet. Pada zaman sebelumnya, yakni televisi dan radio hanya sebatas yang kita ke tahui, karena kita tidak bisa semaunya menginginkan siaran dari televisi dan radio tersebut. Siaran masih di kontrol oleh orang yang memegang kendali di dunia media. Sementara, manusia yang hidup di zaman internet, tidak lagi dibatasi oleh ruang dan waktu, segala-galanya bisa diakses dengan mudah dan dengan biaya yang cukup lumayan murah. Bahkan, dalam waktu 24 jam kita bisa menonton, mendowload sesuka mau kita tanpa dibatasi ruang dan waktu.

Saat ini, manusia telah hidup di era digital, mengalami perkembangan teknologi yang luar biasa. Manusia tidak bisa hidup tanpa teknologi. Teknologi adalah segala-galanya bagi manusia, sehingga dampak positif dan negatif bagi manusia ikut juga menaunginya. Dampak negatif yang sangat dirasakan dari kecanggihan era digital saat ini sungguh terlihat dengan jelas sekali, seperti tingkah laku moral anak yang cukup memprihatinkan. Oleh karena itu, peran pola asuh orangtua dalam lingkungan keluarga, sangat menentukan nilai-nilai yang didapatkan oleh anak.

Dalam sebuah artikel yang ditulis oleh Wawan Setiawan, bahwa anak-anak yang tidak terlepas dari barang-barang teknologi, maka sistem pendidikan yang tepat untuk diberikan kepada anak yang hidup di era digital ini adalah sistem pendidikan "Model Parenting Immun Selfer". Model pendidikan ini, sebagai selaku orangtua menjadi pendamping bagi anak, disaat 
anak memainkan teknologi, dengan tujuan agar anak-anak tidak kecanduan dengan barangbarang teknologi (Setiawan, 2017). Jika dilihat secara sepintas, maka ada juga benarnya, tetapi jika dilihat lebih mendalam, bahwa orangtua mempunyai kesibukan tersendiri untuk memenuhi kebutuhan keluarganya, baik sandang, papan dan pangan. Jadi, rasanya tidak mungkin juga, orangtua selalu mendampingi anaknya untuk setiap saat.

Selanjutnya, dalam penelitian Nasrun Faisal, dengan judul artikel "Pola asuh orang tua dalam mendidik anak di era digital", lebih menekankan pada interaksi dari kebutuhan fisik dan kebutuhan psikologis, seperti rasa aman, kasih sayang, serta sosialisasi dalam kehidupan masyarakat. Sementara, asumsi pendidikan anak di era digital, Faisal lebih menekankan pola asuh orangtua yang bersifat otoriter, yang mana orangtua tidak perlu memaksakan kehendaknya, karena anak tidak senang dipaksa, tetapi sebagai orangtua harus mengontrol teknologi yang dimiliki oleh anak. Pengontrolan itu, sebagai orangtua memeriksa aplikasi apa saja yang terdapat di telepon pintar yang anak miliki (Faisal, 2016). Kedua tesis dari artikel ini, sangat bertentangan dengan pendapat Penulis, yang mana hasil penelitian penulis (Aslan, 2017), yang mengkaji tentang pendidikan remaja dalam lingkungan keluarga dengan perspektif pendidikan Islam di Desa Merabuan Kecamatan Tangaran yang berada di salah satu Kabupaten Sambas Provinsi Kalimantan Barat. Hasil penelitian tersebut menunjukkan, bahwa remaja yang tinggal di daearah Pedesaan yang jauh dari keramaian, bahkan perkotaan, tetapi remaja-remaja, lebih terbawa pengaruh dari media televisi. Penelitian ini dilakukan pada saat di zaman media televisi yang sudah mulai membanjiri rumah di Desa Merabuan. Sementara, media komunikasi seperti teknologi ponsel pintar masih belum dimiliki sama sekali oleh remaja-remaja Desa Merabuan, sehingga media televisi yang menjadi idola mereka. Pada saat itu, yang lagi menjadi idola bagi mereka adalah Group Band, seperti ST 12, Armada, Ungu dan lainnya. Dari Vokalis Group Band tersebut yang paling disenangi oleh remaja Merabuan adalah masalah anting-anting yang dipakainya, sehingga anak terinternalisasi dari anting tersebut. Padahal, sebagai orangtua telah berbagai macam menasehati anaknya, tetapi anak masih tetap berisi keras untuk mencontoh style artis tersebut. Kajian dari penelitian ini, dilakukan di era informasi media televisi. Seandainya dilakukan di era informasi mutakhir saat ini, mungkin lebih menarik dari tingkah laku remaja-remaja yang ada di Desa Merabuan yang bersangkutan. Dari penelitian ini, 
hanya dilakukan di daerah Merabuan. Jika dilakukan di daerah yang lain dengan perkembangan teknologi sekarang, maka mungkin menghasilkan tingkah laku anak yang bermacam ragam. Keanekaragaman itulah, sangat penting untuk kita ketahui dari tipe pola asuh yang diberikan oleh orangtua kepada anaknya.

Menurut Hurlock, untuk mengantisipasi anak-anak di zaman era digital sekarang, yang paling berkesan adalah pola asuh. Sistem pola asuh ini juga, menampilkan teladan yang baik oleh orangtua kepada anaknya (Tridonanto, 2014). Selain itu juga, orangtua yang hidup di zaman era digital ini, bukan juga hanya menguasai teknologi di zaman sekarang, tetapi mempunyai pengetahuan-pengetahuan terhadap perkembangan anaknya (Muhammad Hayyumas, 2016; Singgih D. Gunarsa \& Yulia Singgih D. Gunarsa, 2008). Apalagi, orangtua merupakan "oase" bagi anak. "Tempat anak mencurahkan isi hatinya, mencari jawab atas rasa keinginan tahunya, dan menjadi model atas beragam peran di masyarakat" (Murdoko, E. W. H, 2017). Pengetahuan yang lebih itulah, yang perlu dimiliki oleh orangtua sehingga berjalannya usia anak, maka perkembangan anak ikut juga menampilkan tingkah laku yang berbeda-beda.

Orangtua yang tidak mengetahui perkembangan anaknya, maka kepribadian anak ikut juga tidak diketahui, sehingga orangtua tidak pernah tepat untuk memperlakukan maupun mendidik anaknya (Murdoko, E. W. H, 2017; Rahman, Mardhiah, \& Azmidar, 2015). Lebih-lebih lagi, pengaruh teman sebaya yang begitu besarnya. Menurut Marini \& Andriani (2005) dalam hasil penelitiannya tentan g pengaruh teman sebaya ini yang dilakukan kepada remaja Sekolah Menengah Umum (SMU) dengan usia 15-18 tahun dengan jumlah 100 orang. Hasil penelitiannya menjelaskan bahwa adanya perbedaan yang signifikan dari pola asuh orangtua dengan tipe authoritative, asertif, authoritarian, permissive dan uninvolved. Namun, sayang sekali penelitian ini hanya merupakan penelitian kuantitatif, sehingga perbedaan tingkah laku anak dari tipe pola asuh orangtua tidak begitu jelas perbedaanya. Perbedaannya hanya terletak pada angka-angka.

Permasalahan-permasalahan bagi orangtua dalam mendidik anaknya, di zaman era digital saat ini seperti yang telah dijelaskan diatas, masih belum ditemukan titik penyelesaiannya (Hasnawati, 2013) sehingga penulis ingin mengkaji lebih jauh tentang peran pola asuh orangtua kepada anak yang hidup di era digital saat ini. Kajian ini walaupun hanya 
menggunakan metode kepustakaan, tetapi sebagai penulis, tidak hanya berkutat kepada teori, tetapi akan memberikan kontribusi juga dari pengalaman-pengalaman penulis, berdasarkan pengamatan yang dilakukan oleh penulis bagi anak-anak yang hidup di zaman era digital. Apalagi, penulis yang dilahirkan di era 80-an yang pasti mengalami perbedaan bagi anak yang lahir di era digital, termasuk peran orangtua dalam mendidik anaknya.

\section{Metode}

Metode dalam penelitian ini adalah kualitatif dalam kajian dokumen. Kajian dokumen yang dimaksud adalah kajian yang mencari literatur sesuai dengan bahan kajian seperti buku, artikel, internet dan lain sebagainya. (Long dalam Marani, 2017). Adapun cara-cara dalam pengumpulan datanya diantaranya; Pertama, melakukan kajian pustaka yang sesuai dengan bahan yang diteliti. Bahan-bahan tersebut dikumpulkan. Kedua, setelah data diperoleh, maka penulis melakukan analisis dengan metode deskriptif sesuai dengan pemahaman penulis. Sumber data dalam kajian ini terdiri dari dua, yakni data primer dan data sekunder. Data primer adalah data yang berkaitan dengan judul dalam penelitian ini, sementara data sekunder adalah data pendukung dari judul penelitian ini (Aslan, 2017).

\section{Hasil dan Pembahasan}

\section{Peran Pola Asuh Orangtua}

Orangtua dalam memberikan pendidikan kepada anaknya tidak terlepas dari perannya. Namun, dalam setiap era perubahan, termasuk juga peran orangtua ikut juga mengalami perubahan. Apalagi, anak yang hidup di zaman era digital pasti berbeda hidup di zaman era 80-an, sehingga pendidikan yang diberikan orangtua kepada anaknya ikut juga mengalami perbedaan.

Pada zaman era digital yang ditandai dengan perkembangan teknologi komunikasi dan informasi, yang mana saat ini media televisi, ponsel pintar telah menjadi menu masakan seharihari, yang tidak lagi memandang usia (Mujiburrahman, 2013). Dari bentuk perubahan teknologi

yang semakin cepat, sehingga peran pola asuh orangtua tidak hanya berkutat dengan pola 
pendidikan di era 80-an, tetapi mengalami perkembangan juga seperti berkembangnya teknologi saat ini. Bahkan, pengertian peran pun ikut juga mengalami perubahan dari sejarah kata peran itu digunakan.

Pada awalnya, kata peran dipakai oleh kalangan drama atau teater yang telah hidup di zaman Yunani Kuno atau Romawi yang diperagakan oleh seorang aktor. Kemudian, kata peran ini sudah mulai menyebar yang bukan hanya dipakai dalam kontes drama, tetapi mulai dipakai pada ranah sosial, seperti posisi dari ranah sosial tersebut, termasuk dipakai juga kepada lembaga pendidikan dalam keluarga yakni orangtua (Suhardono, 2016). Berawal dari inilah, Kamus Besar Indonesia, mengartikan peran adalah tokoh dalam sebuah drama. ("Arti kata peran - Kamus Besar Bahasa Indonesia (Tim Redaksi Kamus Besar Bahasa Indonesia Pusat Bahasa, 2009). Berawal dari ini jugalah, tulisan ini menggunakan peran tetapi dalam lingkup orangtua, sehingga peran orangtua yang penulis maksud adalah bimbingan yang dilakukan oleh orangtua terhadap anaknya, dimulai sejak lahir sampai mengenalkan terhadap barangbarang teknologi sesuai dengan era informasi saat ini.

Sementara, pengertian pola asuh diberikan penjelasan oleh beberapa tokoh psikologi dan sosiologi, diantaranya; Pertama., Singgih D Gunarsa, pola asuh adalah "sebagai gambaran nyata dipakai orang tua untuk mengasuh (merawat, menjaga, mendidik) anak. Kedua, Chabib Thoha, pola asuh adalah salah satu cara yang terbaik sebagai tanggung jawab orang tua ke anak. Ketiga, Sam Vaknin, pola asuh adalah sebagai "parenting is interaction betwee parent's and children during their care" (Tridonanto, 2014). Keempat., Menurut Nasrun Faisal (2016), Pola asuh adalah interaksi yang dilakukan antara orangtua dan anak yang meliputi pemenuhan kebutuhan fisik dan kebutuhan psikologis. Kelima., Kohn, pola asuh orangtua terhadap anaknya adalah melalui interaksi dengan anak-anaknya, yang mana perlakukan ini terdiri dari "memberi aturan-aturan, hadiah maupun hukuman, cara orangtua menunjukkan otoritas dan juga cara orangtua memberikan perhatian serta tanggapan kepada anaknya" (Susanto, 2015).

Dengan demikian, dari beberapa pengertian tersebut, pola asuh orangtua artinya tidak terlepas dari pengawasan orangtua terhadap anaknya. Segala-galanya tingkah laku anak, maka akan diawasi, dibimbing oleh orangtua. Dari anak lahir, sampai sudah menikah, walaupun orangtua sebenarnya sudah selesai tanggung jawabnya, tetapi kasih orangtua tidak akan habis 
kepada anaknya. Dalam hal ini, Rasulullah Saw juga mengingatkan kepada manusia, bahwa "Surga terletak ditelapak kaki Ibu". Kemudian, bagi anak yang melakukan perbuatan negatif, maka hasilnya pun ikut terjangkit kepada orangtua. Pepatah juga sering mengingatkan kita, bahwa apa yang kita tanam, maka hasilnya akan ikut kita petik juga. Oleh karena itu, peran orangtua sangat utama dalam pembentukan karekter anak, yang mana peran tersebut tidak terlepas dari tipe pola asuh orangtua.

Penelitian tentang pola asuh, sudah dilakukan sejak pertengahan abad ke 20, yang dilakukan oleh Baumrind. Dari penelitian ini, Baumrind membagi tiga pola asuh yang berbedabeda, diantaranya otoriter, permisif dan demokratis (Hasnawati, 2013). Ketiga tipe pola asuh ini, diantaranya; Pertama, pola asuh orangtua tipe otoriter adalah orangtua yang berusaha untuk "membentuk, mengendalikan, dan mengevaluasi, perilaku serta sikap anak" berdasarkan kemauan orangtua. Kemauan orangtua dari tipe ini, selalu menginginkan kebaikan terhadap anaknya, tetapi malah anak justru salah tanggap terhadap orangtua, sehingga anak merasa tertekan atau stress bahkan bisa juga menimbulkan depresi. Kedua, pola asuh permisif adalah menerima dengan secara terbuka kemauan anak, tetapi kepada hal yang positif, apa yang anak kerjakan. Tipe ini juga, orangtua sangat longgar terhadap anak sehingga anak diberi kebebasan semaunya. Ketiga, pola asuh orangtua tipe demokratis atau autoritatif adalah mengarahkan anak secara rasional dan selalu sikap terbuka kepada anak, dan mengajari anak untuk selalu hidup mandiri. Pola asuh tipe demokratis, anak lebih condong melihat dampak negatif terhadap sesuatu yang dilakukannya, sehingga anak lebih menjauh jika terjadi sesuatu yang dianggap mencelakakan dirinya, misalnya perkelahian antar pelajar (Afiif \& Kaharuddin, 2015; Faisal, 2016; Fellasari \& Lestari, 2017; Marini \& Andriani, 2005; Rahman dkk., 2015; Susanto, 2015; Widyarini, 2009). Selain tiga pola asuh di atas, ada juga pengasuhan anak ala Rasulullah Saw pada saat ini lebih sering dikenal dengan istilah prophetic parenting. Konsep dalam prophetic parenting adalah mendidik anak dengan berkiblat pada cara-cara yang dilakukan Rasulullah dalam mendidik keluarga dan sahabat beliau (Hairina, 2016).

Dari beberapa pengertian tersebut, maka setiap orangtua memiliki karakter yang berbeda-beda sehingga pola asuh yang diberikan kepada anaknya ikut juga mengalami perbedaan, yang bukan hanya dilihat dari tingkat pendidikan orangtua tetapi sejarah 
perjalanan hidup yang ditempuh oleh orangtua yang bersangkutan. Karena setiap pengalaman orangtua memiliki perbedaan, sehingga dari pengalaman tersebut, lebih-lebih lagi pengalaman yang sakit ditempuh oleh orangtua, maka orangtua berasumsi untuk mengubah hidupnya melalui keturunannya. Dari pengalaman inilah, orangtua sudah mulai mengambil peran pengasuhan yang dilakukan oleh anak-anaknya.

\section{Teknologi Era Digital}

Sejarah perjalanan teknologi di dunia ini, ikut juga mewarnai para-para pemikir dunia untuk melakukan sebuah penelitian. Karena seiring berjalannya waktu, teknologi mengalami perkembangan yang semakin pesat, sehingga dari perkembangannya tersebut tidak lagi bisa untuk di ramalkan. Teknologi yang tidak terlepas dari media atau sebagai penyampai yang dimulai dengan memerlukan waktu yang lama, sekarang hanya hitungan perdetik, pesan tersebut sudah bisa sampai. Dari perjalanan demi perjalanan itulah, banyak pemikir sosial untuk melihat perkembangan teknologi.

Teknologi mengalami sejarah perjalanan yang menimbulkan dampak "trendsetter" yang artinya "One that sets a trend". Dalam arti komunikasi "trendsetter" artinya perjalanan media dari waktu ke waktu. Media yang artinya sebagai perantara, digunakan pada masa era pemerintahan kerajaan, yang mana pada waktu itu, belum ditemukan alat tulis sehingga yang menjadi media pada pertama kalinya adalah menggunakan cerobong asap dan diutus sebagai perantaranya adalah manusia untuk menyampaikan pesan tersebut kepada raja yang lain, yang tinggal di daerah yang berbeda. Setelah alat tulis ditemukan, maka manusia menggunakan perantara burung merpati untuk menyampaikan pesan (Bakti \& Meidasari, 2014). Dengan ditemukannya alat tulis, tetapi masih mengalami hambatan, karena jumlah yang ditulis hanya sedikit sehingga hanya sedikit juga yang menikmati dari hasil tulisan tersebut. Akhirnya, pada tahun 1450, ditemukanlah mesin cetak oleh Johan Gutenburg, tetapi masih saja mengalami hambatan, karena masyarakat masih banyak yang buta huruf. Bagi yang bisa membaca, menikmati hasil tulisan tersebut., sementara yang tidak bisa membaca hanya sebagai penikmat pendengar. Namun, perkembangan teknologi bukan hanya sebatas itu saja, sehingga ditemukanlah media elektronik lainnya yakni radio. Masyarakat yang tidak bisa membaca, 
maka bisa mendengar melalui pesan radio. Kemudian, berkembang dengan pesatnya, yang bukan hanya radio, tetapi sudah mulai televisi, ponsel pintar dan teknologi lainnya. Hasil perkembangan mutakhir teknologi di era digital ini adalah internet (Mujiburrahman, 2015).

Perkembangan internet ini juga, baru mulai booming, sejak tahun 1996. Dalam kurun waktu 15 tahun, berdasarkan dari statistik BLS American Time Use Survey data global Web index, negara Indonesia merupakan pengguna internet dan media terbesar di Asia (Santosa, 2015). Dari perkembangan internet tersebut sehingga jaringan sosial mulai diperkenalkan bagi pelaku sosial dan ekonomi, baik "MySpace, Facebook, Twitter, Instagram, Line, dan lain-lain" (Setiawan, 2017; Sugihartati, 2014). Dalam hal ini, peneliti dari Amerika Serikat yang meneliti tentang perkembangan teknologi yakni Don Tapscoot (Wuryantai, 2004), menjelaskan bahwa berkembangnya teknologi membuat manusia mengalami dinamika perubahan masyarakat yang baru. Ungkapan tersebut adalah "information is the lifeblood that sustains political, social and business decision". Manusia mengalami perubahan yang luar biasa di zaman ini. Segala-galanya telah mengubah hidup manusia menjadi mudah, murah, tergantung manusia memanfaatkan teknologi tersebut.

Wuryantai (2004) dalam memaknai perkembangan teknologi mempunyai sifat yang konvergen, dengan melalui tiga tahapan. Pertama, perubahan dalam proses komunikasi yang meliputi "digitalisasi, perluasan teknologi serat optik dan networking technology. Kedua, perkembangan "soal networking", yang mana teknologi mampu menghadirkan dengan berbagai macam bentuk, baik angka, simbol, warna, gerak dan lain sebagainya. Ketiga, "teknologi multimedia" yang telah mengubah komunikasi tradisional menjadi digital. Jika dilihat dari perkembangan teknologi ini, bahwa perkembangannya tidak terlepas dari jaringan. Dalam istilahnya, jaringan ini lebih dikenal dengan perantara, sehingga disebutlah media. Namun, perantara di zaman dahulu dengan sekarang sudah mengalami perubahan. Dan jaringan yang paling dianggap mutakhir saat ini adalah internet. Akan tetapi, setiap yang menjadi perantara, maka tidak terlepas dari hambatan-hambatan. Pada saat pesan melalui asap, yang menjadi hambatannya adalah masalah angin. Karena kita tidak bisa menentukan arah, tetapi hanya ditentukan oleh angin. Untuk mengatasi hal tersebut, maka diutuslah orang yang menyampaikannya, tetapi memerlukan waktu yang lama. Pada saat menyampaikan pesan 
melalui burung merpati, maka yang menjadi hambatannya adalah memerlukan burung yang memang-memang benar terlatih. Sejak dari itu, setiap teknologi mengalami perubahan dan perkembangan, maka tidak terlepas dari hambatan-hambatannya dan dampaknya. Saat ini, internet merupakan teknologi yang sungguh luar bisa untuk menyampaikan pesan, tetapi hambatannya adalah uang. Jika tidak ada uang, maka tidak bisa juga untuk memakai internet.

\section{Dampak Perkembangan Teknologi Era Digital Terhadap Anak}

Manusia yang hidup di era digital, dengan tidak dibatasi terhadap kecanggihankecanggihan yang ada, sehingga dampak positif maupun negatif ikut juga menaunginya. Akan tetapi, bagi yang memanfaatkan teknologi secara positif, maka teknologi bermanfaat bagi dirinya. Bahkan, dia bukan saja menguasai teknologi, tetapi teknologi tidak bisa untuk menguasainya. Sementara, jika berlebih-lebihan dalam memanfaatkan teknologi, sehingga teknologi membawa dampak negatif baginya, maka dia bukan saja menguasai teknologi, tetapi teknologi juga telah menguasainya, bahkan telah merubahnya menjadi monster yang menakutkan.

Menurut Alvin Toffler (dalam Santosa, 2015), dampak teknologi dapat mengakibatkan "our technological powers increase, but the side effects and potential hazards also escalate". Sementara, menurut Setiawan (2017) dari Universitas Pendidikan Indonesia, bahwa dampak Postif dan negatif teknologi di era digital ini, antaranya: Pertama., Dampak positif di era digital adalah; a). Informasi yang dibutuhkan lebih cepat dan mudah dalam mengaksesnya; b). Kemudahan dalam bekerja karena di dukung oleh teknologi digital; c). Sumber pengetahuan masyarakat semakin meningkat, karena kehadiran media dalam digital; d). Kualitas sumber daya manusia semakin meningkat, karena bisa belajar dari teknologi digital; e). Kualitas pendidikan semakin meningkat karena adanya kehadiran sumber belajar, seperti “perpustakaan online, media pembelajaran online, diskusi online"; f). Munculnya bisnis toko on-line, yang mana masyarakat bisa saja pesan melalui online, tanpa lagi perlu keluar rumah untuk membeli barang-barang yang diperlukan. Kedua., dampak negatif dari era digital adalah; a). Pelanggaran atas "Hak Kekayaan Intelektual (HKI)" yang dapat menyebabkan plagiarisme tulisan orang; b). Pikiran 
semakin pendek dan kurang konsentrasi; c). Penyalahgunaan pengetahuan, seperti menerobos sistem perbankan; d). Tidak efektifnya kegiatan yang dilakuan dari kemudahan era digital ini.

\section{Urgensi Sinkronisasi Pola Asuh Orangtua di Era Digital}

Perubahan teknologi tidak terlepas dari dampak positif maupun negatif. Oleh karena itu, sebagai selaku orangtua harus mengantisipasi perilaku anaknya terhadap teknologi yang digunakan oleh anak. Lebih-lebih lagi saat ini, permainan anak di zaman era 80-an telah tergantikan oleh telepon pintar, tablet pintar sehingga keseharian anak hanya berkutat dilayar kecil dengan berbagai macam tipe permainan.

Kehidupan anak di zaman era digital, tidak terlepas dari telepon pintar dengan berbagai macam permainan di aplikasi game, sehingga keseharian anak dihabiskan dengan barang-barang teknologi (Santosa, 2015). Perkembangan media tersebut yang berdampak pada keluarga, sebagaimana yang diutarakan oleh Ogburn, bahwa perubahan pada keluarga saat ini telah menjadi kebudayaan adaptif (Thromi, 2004). Selain itu juga, pola asuh dari orangtua kepada anaknya mengalami perubahan disebabkan oleh kemajuan ekonomi, teknologi dan persamaan derajat (Ihromi, 2004). Hal yang paling menarik menurut hemat penulis, bahwa adanya perkembangan teknologi sehingga jurang perbedaan semakin tampak terhadap keluarga antara yang satu dengan yang lainnya, misalnya, orangtua si A membelikan anaknya tablet pintar, maka orangtua si B, ikut juga membelikan. Peran pola asuh orangtua yang pada awalnya dianggap penting, tetapi karena dengan perubahan teknologi tersebut sehingga orangtua memberikan pendidikan kepada anaknya semakin terabaikan. Orangtua tidak mementingkan pola asuh yang diberikan kepada anaknya, tetapi hanya mementingkan jurang perbedaan tersebut, sehingga untuk memenuhi kebutuhan si anak, dan mengobati jurang perbedaan tersebut, maka orangtua disibukkan dengan bekerja tanpa memikirkan anaknya.

Dengan demikian, berdasarkan hasil riset, tipe pola komunikasi orangtua di zaman era digital, terdapat empat tipe, diantaranya (Muhammad Hayyumas, 2016): Pertama, "Pola Konsensual, adanya musyawarah mufakat". Pola komunikasi dari tipe ini, bahwa selaku

orangtua dengan senang sekali mengajak mengobrol anak-anaknya. Namun, segala keputusannya terletak kepada orangtua, walaupun berbeda dengan kemauan anak, tetapi 
alasan ketidaksetujuan orangtua terhadap kemauan anak dijelaskan dengan mendalam sehingga anak lebih mengerti dan memahami, mengapa orangtuanya tidak menyetujui keinginannya. Kedua, pola pluralistik. Komunikasi ini lebih terbuka, sehingga orangtua sering berbicara dengan anak. Bahkan, keputusan diserahkan kepada anak semuanya, yang penting keputusan itu adalah baik. Anak lebih berpikir secara bebas. Ketiga, pola protektif. Komunikasi orangtua dengan anaknya sangat jarang sekali, tetapi sifat kepatuhan atau norma dalam keluarga sangat tinggi, sehingga tipe ini, jika anak marah, maka akan lebih mudah di pujuk. Keempat, Pola laissez-faire. Pola ini jarang dilakukan oleh orangtua sehingga sering terjadi kesalahan dalam komunikasi antara orangtua dan anak.

Dari beberapa pola komunikasi tersebut, sama juga halnya dengan tipe pola asuh orangtua, baik otoriter, demokratis maupun permisif. Namun, dari beberapa pengamat penulis, bahwa ketiga pola asuh ini perlu disinkronisasikan sesuai dengan situasi dan kondisi perilaku anak. Karena, sebagai selaku orangtua, tidak hanya menekankan pada satu pola asuh, tetapi harus menggunakan ketiga pola asuh tersebut. Oleh karena itu, urgensi mendidik anak di era digital, sebagai selaku orangtua, wajib mengetahui perkembangan anak. Pola asuh otoriter diberlakukan kepada anak sesuai dengan situasi dan kondisi yang diperlukan. Orangtua berhak untuk memberikan kebebasan sebagaimana pola asuh permisif tetapi dalam hal negatif, sehingga ketiga pola asuh ini, baik otoriter, permisif dan demokratis masing-masing bekerjasama terhadap dampak yang dihasilkan oleh teknologi, misalnya jika pada waktu anak sedang belajar, maka orangtua mengontrolnya dengan sebaik mungkin, agar dalam kegiatan pembelajaran yang dilakukan oleh anak, maka anak tidak membawa telepon genggam. Orangtua selalu menasehati dan selalu berinovasi tentang masa depan anak, dan selalu memberikan hal yang positif terhadap apa yang dilakukan oleh orangtua adalah untuk kebaikan anak. Namun, segala-gala yang dilakukan oleh orangtua dalam pola asuhnya tidak terlepas dari tahap perkembangan moral anak, karena setiap jenjang usia anak, maka sistem pendidikan yang diberikan pun sesuai dengan tahap moral tersebut.

Menurut Fraenkel (1977) dan Kohlberg (1978), tingkat perkembangan anak terdiri dari Pra konvensional, konvensional dan pasca konvensional. Pada tingkat Pra konvensional, dengan umur anak 4-10 tahun, maka anak masih mematuhi ucapan orangtuanya. Anak takut 
terhadap hukuman, jika tidak mematuhi perintah orangtua. Anak pada tahap ini, maka tipe pola asuh orangtua adalah sinkronisasi antara otoriter, demokratis dan permisif. Tipe otoriter digunakan oleh orangtua pada saat anak mulai bertingkah, misalnya pada saat anak minta belikan sesuatu tetapi orangtua tidak mempunyai uang, maka orangtua sudah mulai keras dengan anaknya. Setelah anak mulai mematuhi ucapan orangtuanya dan tidak ngotot untuk meminta belikan barang tersebut, maka pada saat malam orangtua menerapkan tipe pola asuh permisif. Orangtua menjelaskan hal-hal yang positif kenapa orangtua tidak membelikan kemauan anak, agar pikiran anak terbuka. Jika, sebagai orangtua hanya diam tanpa memujuk anak, nanti anak akan dendam kepada orangtuanya, sehingga tipe demokrasi orangtua kepada anaknya ikut juga diterapkan pada situasi kondisi ini. Sementara, anak pada tingkat konvensional dengan umur 10-13 memerlukan teladan dari orangtuanya. Disaat anak ingin bermain dengan orangtua, maka sebagai orangtua meluangkan waktu untuk bermain dengan anak, bukan sebaliknya, yakni orangtua hanya disibukkan dengan pekerjaan dan teknologi. Tahap demi tahap tipe pola asuh yang diberikan kepada anak, maka anak sudah terbiasa dengan didikan orangtuanya dalam lingkungan keluarga, sehingga anak di saat berada di lingkungan masyarakat atau anak sudah sampai pada tingkat pasca konvensional, maka anak tidak terpengaruh dengan gejolak sosial di lapangan masyarakat. Misalnya, anak melihat temannya bermain telepon pintar, maka anak yang telah dididik dengan tipe pola asuh sinkronisasi mengetahui dampak dari teknologi yang dimainkan oleh temannya, sehingga anak tidak mempunyai niat untuk meminta belikan barang-barang teknologi tersebut yang dimiliki oleh temannya.

\section{Kesimpulan}

Peran orangtua dalam mendidik anaknya tidak terlepas dari pola asuh yang diterapkan oleh orangtua. Di zaman era digital saat ini, dengan berbagai macam kecanggihan teknologi sehingga tipe pola asuh orangtua kepada anaknya ikut juga mengalami perubahan. Tipe pola asuh yang terdiri dari otoriter, demokrasi dan permisif, dengan mengalami sistem pola asuh yang berbeda-beda yang diberikan oleh orangtua kepada anaknya sehingga menghasilkan karakter yang berbeda-beda juga kepada anak. Oleh karena itu, perubahan teknologi semakin 
pesat dari waktu ke waktu, maka sebagai selaku orangtua, seharusnya tidak tinggal diam dengan perkembangan yang ada terhadap pola asuh anaknya, tetapi harus melakukan perubahan juga, sehingga teknologi yang mengalami perubahan tetapi pola asuh anak ikut juga mengalami sinkronisasi antara peran pola asuh tipe otoriter, demokratis dan permisif.

Saran

Kajian dalam penelitian ini menggunakan kajian literatur sehingga bagi peneliti selanjutnya dapat melakukan penelitian lapangan, sehingga hasil penelitian ini bisa menyesuaikan dengan lapangan yang ada, karena sebagai peneliti juga, bahwa kajian ini bukanlah hanya sebagai literatur saja tetapi berdasarkan pengalaman penulis dan observasi dilapangan.

\section{Referensi}

Afiif, A., \& Kaharuddin, F. (2015). Perilaku Belajar Peserta Didik Ditinjau Dari Pola Asuh Otoriter Orang Tua. AULADUNA: Jurnal Pendidikan Dasar Islam, 2(2), 287-300.

Aslan, A. (2017). Pumping Teacher dalam Tantangan Pendidikan Abad 21. Muallimuna, 2(2), 89100.

Bakti, A. F., \& Meidasari, V. E. (2014). Trendsetter Komunikasi di Era Digital: Tantangan dan Peluang Pendidikan Komunikasi dan Penyiaran Islam. Jurnal Komunikasi Islam, 4(1).

Faisal, N. (2016). Pola Asuh Orang Tua dalam Mendidik Anak di Era Digital. Jurnal An-Nisa, 9, 121-137.

Fellasari, F., \& Lestari, Y. I. (2017). Hubungan Antara Pola Asuh Orangtua Dengan Kematangan Emosi Remaja. Jurnal Psikologi, 12(2), 84-90.

Fraenkel, J. R. (1977). How to teach about values: An analytic approach. New Jersey: Prentice-Hall Englewood Cliffs, New Jersey.

Hairina, Y. (2016). Prophetic Parenting Sebagai Model Pengasuhan dalam Pembentukan Karakter (Akhlak) Anak. Jurnal Studia Insania, 4(1), 79-94.

Hasnawati, H. (2013). Pendidikan Akhlak Dalam Pola Asuh Orang Tua. None, 28(3), 439-454.

Ihromi, T. (2004). Berbagai Kerangka Konseptual dalam Pengkajian Keluarga, Bunga Rampai Sosiologi Keluarga. Jakarta: Yayasan Obor.

Kohlberg, L. (1978). Revisions in the theory and practice of moral development. New directions for child and adolescent development, 1978(2), 83-87.

Marani, A. (2017). Kurikulum Bagi Anak Berkebutuhan Khusus (ABK). Jurnal Studia Insania, 5(2), 105-119.

Marini, L., \& Andriani, E. (2005). Perbedaan Asertivitas Remaja Ditinjau Dari Pola Asuh Orang Tua. 46-53.

Muhammad Hayyumas. (2016). Pola Interaksi Hubungan Orang Tua Dengan Anak di Era Digital (Studi Deskriptif Kualitatif Pola Interaksi Hubungan Orang Tua dengan Anak di Era Digital 
Dalam Mengatasi Ketergantungan Anak Terhadap Teknologi Informasi dan Komunikasi Di Era Digital Di Kalangan Komunitas Cinta Anak Solo) (Skripsi). Universitas Sebelas Maret, Surakarta.

Mujiburrahman. (2013). Bercermin Ke Barat: Pendidikan Islam Antara Ajaran dan Kenyataan (Cetakan Pertama). Banjarmasin: Jendela.

Mujiburrahman. (2015). Agama, Media Dan Imajinasi: Pandangan Sufisme Dan Ilmu Sosial Kontemporer (Cetakan 2). Banjarmasin: Antasari Press.

Mujiburrahman. (2017a). Agama Generasi Elektronik (Cetakan Pertama). Yogyakarta: Pustaka Pelajar.

Mujiburrahman. (2017b). Humor, Perempuan dan Sufi. Jakarta: Gramedia Pustaka Utama.

Murdoko, E. W. H. (2017). Parenting With Leadership Peran Orangtua Dalam Mengoptimalkan Dan Memberdayakan Potensi Anak. Jakarta: Elex Media Komputindo.

Rahman, U., Mardhiah, M., \& Azmidar, A. (2015). Hubungan Antara Pola Asuh Permisif Orang Tua dan Kecerdasan Emosional Siswa dengan Hasil Belajar Matematika Siswa. AULADUNA: Jurnal Pendidikan Dasar Islam, 2(1), 116-130.

Santosa, E. T. (2015). Raising Children In Digital Era. Jakarta: Elex Media Komputindo.

Setiawan, R. (2017). Kebebasan Ekspresi Individual dalam Pembangunan Manusia Era Digital. 1.

Singgih D. Gunarsa, \& Yulia Singgih D. Gunarsa. (2008). Psikologi Perkembangan Anak Dan Remaja (Cetakan Ke 13). Jakarta: BPK Gunung Mulia.

Sugihartati, R. (2014). Perkembangan masyarakat informasi $\mathcal{E}$ teori sosial kontemporer. Jakarta: Kencana.

Suhardono, E. (2016). Teori Peran: Konsep, Derivasi dan Implikasinya. Jakarta: Gramedia Pustaka Utama.

Susanto, A. (2015). Bimbingan dan konseling di taman kanak-kanak. Jakarta: Prenada Media.

Tim Redaksi Kamus Besar Bahasa Indonesia Pusat Bahasa,. (2009). Kamus Besar Bahasa Indonesia Pusat Bahasa; Edisi Keempat (Vol. 11). Jakarta: Gramedia Pustaka Utama.

Toffler, A. (1980). The third wave. New York: William Morrow and Company. New York City: William Morrow and Company, INC.

Tridonanto, A. (2014). Mengembangkan pola asuh demokratis. Jakarta: Elex Media Komputindo.

Widyarini, N. (2009). Relasi orang tua dan anak. Jakarta: Elex Media Komputindo.

Wuryantai, A. E. W. (2004). Digitalisasi Masyarakat: Menilik Kekuatan dan Kelemahan Dinamika Era Informasi Digital dan Masyarakat Informasi. Ilmu Komunikasi, 1(2), 131142. 